\title{
INTERACTIVE LEARNING MULTIMEDIA: ENHANCING VOCABULARY MASTERY FOR JUNIOR HIGH SCHOOL STUDENTS
}

\author{
Wahyu Budiyani dan Sujarwo \\ Graduate School Yogyakarta State University \\ email:wahyubudiyani.2017@student.uny.ac.id
}

\begin{abstract}
This study was aimed at improving junior high school students' vocabulary mastery. The subjects of this study were the students grade 7 of junior high school with a total number of 60 students. The method employed in this study was the Research and Development design. The development model used is the ADDIE modification development model. The steps in the ADDIE development consist of five stages; namely analyzing, design, development, implementation, and evaluation. Product trials are carried out in three stages, namely small group trials, operational trials, and large group trials.. The instruments used in development research were observation sheets, interviews, and assessment questionnaires. A $t$-test was used to analyze the effectiveness of media development. The media then were validated by the media experts, material experts, and teachers. The results shows that the media is feasible with an average score of 4.55. The findings also show that the Interactive Learning Multimedia effectively enhance students' vocabulary mastery for junior high school students and able to be used as a catalyst or alternative media teaching vocabulary.
\end{abstract}

Keywords: interactive learning multimedia, English learning, vocabulary

\section{INTRODUCTION}

The importance of English in the Indonesian education context can be seen as one of the subjects in the national exam. The Regulation of the Minister of National Education of the Republic of Indonesia Number 46 of 2010 Chapter IV point 9, with the inclusion of English in the National Examination, expects that students' abilities in learning English will increase. National education hopes that students will be able to continue to improve their English skills in terms of writing, pronunciation, and usage. However, in the process of learning in the classroom, students still face difficulties in learning English vocabulary. Their mastery of English vocabulary is still low. This is derived from many factors, both from internal and external factors such as learning motivation, student intelligence, learning styles, environmental factors, and learning media. As explained by Papilaya and Huliselan (2016), students have different learning styles which can influence students' understanding of learning.

Vocabulary has an important role in learning English. Yet, in the process of learning English in Indonesia at the junior high school level, there are no specific subjects that teach students to master English vocabulary. This is also stated by Nunan (1991) who explains that vocabulary is the basis for people to speak so that the information provided is in accordance with the aims and objectives. If students do not know the meaning of the vocabulary that they read or listen to in the learning process, there will be problems of misunderstanding pertinent to vocabulary. Added to this, Khan (2011) explains that the technological revolution and English e-learning system have emerged as one of 
the most widely used in the world as an important formal communication tool in the current era, the cyber and digital era. Therefore, students must also master the English vocabulary since it will help them in learning and mingling with other people in this cyber era. Learning vocabulary is viewed as an input-driven process in which it measures to emerge from user experience with the language (Harrington, 2018), that in learning English vocabulary is a learning process where students will have learning experiences in a particular language specifically English language.

The difficulties that are often encountered by students when learning English are to master the English vocabulary, this is in accordance with the results of the interviews conducted by the researchers on $7^{\text {th }}$ grade students of SMP N 2 Turi and the English teachers. While the result of observations on students when learning English in class 7 at $S M P$ N 2 Turi is obtained through the information that students have difficulty in mastering English vocabulary. They do not know the meaning of English words. Another reason that makes them difficult in learning English is that English is not a native language for them. Another factor that makes $7^{\text {th }}$ grade students of SMP N 2 Turi find it difficult to master English vocabulary at school is the lack of supporting learning media. Teachers only use media-books and worksheets in the learning process without using other supporting media. Media is not the main tool in the learning process in the classroom. Learning media can help students more easily remember and memorize the learning materials, especially memorizing English vocabulary.

According to Ahmad's opinion (2010) in the process of teaching English vocabulary, teachers should often repeat words with a drill and practice system, teachers can use interesting media so that students can learn vocabulary with focus. However, this is rarely found in schools, especially in SMP N 2 Turi where English teachers only use the media-books and worksheets without the support of other media that are more interesting and make students more focus on learning. And the methods used are still using conventional and lecturing methods. Meanwhile, according to Sanaky (2013) learning media is an educational tool that can be used as an intermediary in the learning process to enhance effectiveness and efficiency in achieving teaching objectives. This leads to how learning objectives can be achieved. In the same vein, Rusman, Kurniawan, and Riyana (2012) also explain that learning media is a tool that allows students to understand and comprehend something easily and remember it for a long time compared to the delivery of material by face to face and lectures without assistive devices. The application of vocabulary teaching with appropriate learning media is effective to foster student learning interest because students are allowed to feel the nuances of learning and new experiences that are more enjoyable.

Based on several obstacles faced by students in mastering English vocabulary, researchers focus on the use of interesting alternative learning media that can help students learn English easily. This will influence the learning process with lecture methods that often make students get bored and unfocused. Interesting learning media and in accordance with the learning needs of $7^{\text {th }}$ grade students of SMP N 2 Turi in improving English vocabulary mastery is interactive learning multimedia (MPI). Development of MPI by researchers is aimed at improving the vocabulary mastery of $7^{\text {th }}$ grade students of SMP N 2 Turi by interestingly presenting material 
and making students more focused on learning.

Munir (2013) argues that interactive learning multimedia is a combination of various media (file format), a combination of various kinds of media (file types) in the form of texts, vector or bitmap images, then graphics, sound or sound, video animations, interactions, and other types that are packaged into one digital data (computerized) and then used to convey or deliver information in the form of messages to the general public. Meanwhile Surjono (2017) explains that interactive learning multimedia is a combination of text, images, graphics, sound, and video, and animation, simulation in an integrated and synergistic manner with the help of certain computer applications to achieve learning objectives. This is in line with Saputra and Purnama (2012) that this multimedia application is expected to facilitate understanding of learning materials. Furthermore, Daryanto (2013) explains that interactive learning multimedia is multimedia that is equipped with a controller that can be operated by the user, so the user can choose what he wants for the next process. Examples of MPI are interactive learning, game applications, and others.

In teaching vocabulary in a classroom, it is quite difficult because English is not the first language used by the students. However, McCarthy and O'Dell (2017) provide ways to teach vocabulary to students. The first thing is that students are given an English text with a few words in bold so that students make the words look more interesting. Then the second is to give meaning to all vocabulary in bold given an explanation of the meaning in the forms of English or Indonesian. Next, the students can be given training by using sentences and ask them to fill in the sentences with the appropriate words. Through MPI the researchers hope to be able to improve their mastery of English vocabulary and make students interested and motivated in learning (Nopriyanti \& Sudira, 2015). From the results of the trial, it was stated that interactive learning multimedia on the basic competencies of installing lighting systems and electrical wiring of subject matter for external lighting systems could improve student learning outcomes. Hence, interactive learning multimedia need to be used to improve students' learning outcomes.

\section{METHOD}

This study is in the model of Research and Development (R\&D) which is aimed at developing and validate the products produced. The product developed is in the form of interactive learning multimedia in mastering English vocabulary in grade 7 SMP N 2 Turi. The development model used is the ADDIE modification development model. The steps in the ADDIE development consist of five stages; namely analyzing, design, development, implementation, and evaluation. Product trials are carried out in three stages, namely small group trials, operational trials, and large group trials.

The instruments used in development research were observation sheets, interviews, and assessment questionnaires. The resulted product quality data comes from the assessment of media experts, material experts, and teachers and then changes the average score of each qualitative indicator into a qualitative value according to the assessment criteria as well as the translation of each aspect of the criteria into a qualitative value (Widyoko, 2009).

A $t$-test was used to analyze the effectiveness of media development. The $t$-test calculations in this study used SPSS software version 16.0 for windows. If the 
Table 1

Interval Convertion of Qualitative and Quantitative Data

\begin{tabular}{cll}
\hline $\begin{array}{c}\text { Quantitative } \\
\text { Data }\end{array}$ & \multicolumn{1}{c}{ Score Interval } & \multicolumn{1}{c}{ Qualitative Data } \\
\hline 5 & $\mathrm{X}>\mathrm{Xi}+1,80 \mathrm{Sbi}$ & Very Good \\
4 & $\mathrm{Xi}+0,60 \mathrm{Sbi}<\mathrm{X}<\mathrm{Xi}+1,80 \mathrm{Sbi}$ & Good \\
3 & $\mathrm{Xi}-0,60 \mathrm{Sbi}<\mathrm{X}<\mathrm{Xi}+0,60 \mathrm{Sbi}$ & Enough \\
2 & $\mathrm{Xi}-1,80 \mathrm{Sbi}<\mathrm{X}<\mathrm{Xi}-0,60 \mathrm{Sbi}$ & Low \\
1 & $\mathrm{X}<\mathrm{Xi}-1,80 \mathrm{Sbi}$ & Very Low \\
\hline
\end{tabular}

$t$-test in the calculation is obtained Sig value $<0.05$, it can be seen that there are differences in student test results. If the Sig value $>0.05$ then there are no differences in student test results in the two classes.

\section{RESULTS AND DISCUSSION}

In this study, several stages are carried out; namely the analysis, design, development, implementation, and evaluation stages. It was conducted at SMP N 2 Turi. The subject in this study was grade 7 of SMP N 2 Turi. After researchers obtained information and problems faced by students, it is necessary to use alternative learning media that can help students learn English easily based on students' needs. One of the media that suits students' needs and interesting learning media is interactive learning multimedia (MPI). The following is an explanation of the results and discussion in the research development of interactive learning multimedia to improve vocabulary mastery in learning English.

The product produced from this research and development is in the form of MPI. The following are the stages of the results of the development of interactive learning multimedia products.

The first stage is analysis to obtain information, constraints faced by students and provide appropriate solutions. The second stage is the design or planning stage that all activities starting from the media planning, the material will be delivered, and the evaluation will be given to students. In the third stage, the development and production stages of MPI are carried out. In the production and development stage, it involves experts, both instrument validators, material experts, media experts with a minimum qualification of two lecturers. After the development of the MPI is completed, then an assessment is made by experts. Table 2 shows the results are obtained from media experts.

In the product due diligence of the media experts, it is obtained 4.55 results that can be categorized as very good. After obtaining an assessment from a media expert then it was proceeded via the material feasibility test conducted by the material expert. The presentation of the results of the assessment from the material experts on the development of MPI as shown in Table 3.

The results of the assessment of the feasibility of interactive learning multimedia in English learning in grade 7 of SMP $\mathrm{N} 2$ Turi by material experts, it has very good scores with a an average score of 4.55.

Interactive learning multimedia assessment by the $7^{\text {th }}$ grade English teacher of SMP N 2 Turi as well as the results of the feasibility assessment of the interactive multimedia of the $7^{\text {th }}$ grade elementary 
Table 2

The Result of Interactive Learning Multimedia by Media Experts

\begin{tabular}{clccl}
\hline No & \multicolumn{1}{c}{ Aspect } & Score & Mark & \multicolumn{1}{c}{ Category } \\
\hline 1 & Media Appearance & 4.5 & "SB" & Very Good \\
2 & Image and Animation & 4 & "B" & Good \\
3 & Texts & 5 & "SB" & Very Good \\
4 & Audio dan Video & 4.7 & "SB" & Very Good \\
\hline \multicolumn{2}{r}{ Average Scores } & 4.55 & & Very Good \\
\hline
\end{tabular}

Table 3

The Result of Interactive Learning Multimedia by Material Experts

\begin{tabular}{clccl}
\hline No & \multicolumn{1}{c}{ Aspect } & Score & Mark & \multicolumn{1}{c}{ Category } \\
\hline 1 & Material Eligibility & 4.1 & "B" & Good \\
2 & Material Accuracy & 4.6 & "SB" & Very Good \\
3 & Language & 5 & "SB" & Very Good \\
4 & Material Novelty & 5 & "SB" & Very Good \\
\hline \multicolumn{7}{r}{ Average Score } & 4.55 & & Very Good \\
\hline
\end{tabular}

school by the English teacher of SMP N 2 Turi is as shown in Table 4 . The results of the feasibility assessment of interactive learning multimedia grade 7 SMP N 2 Turi by English teachers of SMP N 2 Turi, it has very good results of 4.55 .

A trial was conducted to obtain responses and effectiveness of interactive learning multimedia when used in learning in $7^{\text {th }}$ grade junior high school. The trial was conducted on $7^{\text {th }}$ grade students of SMP N 2 Turi. Student responses were obtained through student questionnaire responses from the aspect of media, content/material aspects, which were then converted to Likert scale values. The procedure of conducting

Table 4

The Result of Interactive Learning Multimedia by Teachers

\begin{tabular}{clccc}
\hline No & \multicolumn{1}{c}{ Indicators } & Score & Mark & Category \\
\hline 1 & Media Appearance & 4 & "B" & Good \\
2 & Image and Animation & 4 & "B" & Good \\
3 & Texts & 4 & "B" & Good \\
4 & Audio dan Video & 4 & "B" & Good \\
5 & Material Eligibility & 4.1 & "B" & Good \\
6 & Material Accuracy & 4.2 & "SB" & Very Good \\
7 & Language & 4.4 & "SB" & Very Good \\
8 & Material Novelty & 4.5 & "SB" & Very Good \\
\hline & Average Score & 4.55 & & Very Good \\
\hline
\end{tabular}


the trial is carried out in three stages; namely small trial groups, operational trial groups, and large trial groups. The results of interactive learning multimedia trials in the English learning process in $7^{\text {th }}$ grade junior high school as shown in Table 5.

The results of small group trials are still relatively low with an average of 2.9 with a sufficient criteria. The next step is the operational test, students fill in the response questionnaire that contains statements about interactive learning multimedia. Student response data includes aspects of MPI media, aspects of content/material. Data on the results of student responses obtained in operational tests are then converted according to Table 6 .

Based on these data, it can be concluded that the students' responses to interactive learning multimedia in the aspect of media, content/material included in the category of "Very Good" with a value of 4.38. Large group trials are slightly different from small group trials and operational tests because they use the experimental method. Besides, it is also a stage of implementing a product on the research subject. The experimental method involves two large classes, namely the experimental class, and the control class. The experimental class is a class that uses interactive learning multimedia in English learning while the control class is a class that uses the $7^{\text {th }}$ grade student's book of SMP 2013 Curriculum. The results of the student responses to the large group trials as shown in Table 7.

Based on the data obtained by students' responses to multimedia interactive learning in the aspect of media, the content/material is included in the excellent category with a score of 4.53. Then the test or evaluation stage is carried out to determine the achievement of the cognitive aspects that emphasize students' knowledge ability to master vocabulary in English that students have. There are two classes

Table 5

The Result of Students' Response in Small Group

\begin{tabular}{|c|c|c|c|}
\hline No & Indicators & Average & Criteria \\
\hline 1 & $\begin{array}{l}\text { Interactive Learning Multimedia makes it easier for me to } \\
\text { understand the material. }\end{array}$ & 3.3 & Enough \\
\hline 2 & $\begin{array}{l}\text { Interactive Learning Multimedia makes it easier for me to } \\
\text { understand English vocabulary. }\end{array}$ & 3.6 & Good \\
\hline 3 & The letters used to make it easy for me to read MPI. & 2.6 & Enough \\
\hline 4 & The proportion of images on the media is appropriate. & 2.6 & Enough \\
\hline 5 & Sound and music quality on the media is good. & 3 & Enough \\
\hline 6 & Use of examples in accordance with daily life. & 3 & Enough \\
\hline 7 & The material in MPI is interesting. & 3 & Enough \\
\hline 8 & $\begin{array}{l}\text { The sentences used in MPI are clear and easy to } \\
\text { understand. }\end{array}$ & 3 & Enough \\
\hline 9 & $\begin{array}{l}\text { The language used in MPI is simple and easy to } \\
\text { understand. }\end{array}$ & 2.3 & Low \\
\hline \multirow[t]{3}{*}{10} & The letters used are simple and easy to read. & 3 & Enough \\
\hline & Total & 29.6 & \\
\hline & Average & 2.9 & Enough \\
\hline
\end{tabular}


Table 6

The Result of Students' Response in Operational Test

\begin{tabular}{|c|c|c|c|}
\hline No & Indicators & Average & Criteria \\
\hline 1 & $\begin{array}{l}\text { Interactive Learning Multimedia makes it easier for } \\
\text { me to understand the material. }\end{array}$ & 3.7 & Good \\
\hline 2 & $\begin{array}{l}\text { Interactive Learning Multimedia makes it easier for } \\
\text { me to understand English vocabulary. }\end{array}$ & 4.2 & Good \\
\hline 3 & The letters used to make it easy for me to read MPI. & 4.5 & Very Good \\
\hline 4 & $\begin{array}{l}\text { The proportion of images on the media is } \\
\text { appropriate. }\end{array}$ & 4.5 & Very Good \\
\hline 5 & Sound and music quality on the media is good. & 4.8 & Very Good \\
\hline 6 & Use of examples in accordance with daily life. & 4.5 & Very Good \\
\hline 7 & The material in MPI is interesting. & 4.6 & Very Good \\
\hline 8 & $\begin{array}{l}\text { The sentences used in MPI are clear and easy to } \\
\text { understand. }\end{array}$ & 4.2 & Very Good \\
\hline 9 & $\begin{array}{l}\text { The language used in MPI is simple and easy to } \\
\text { understand. }\end{array}$ & 4.4 & Very Good \\
\hline \multirow[t]{3}{*}{10} & The letters used are simple and easy to read. & 4 & Good \\
\hline & Total & 43.8 & \\
\hline & Average & 4.38 & Very Good \\
\hline
\end{tabular}

Table 7

The Result of Students'Response in Big Group

\begin{tabular}{|c|c|c|c|}
\hline No & Indicators & Average & Criteria \\
\hline 1 & $\begin{array}{l}\text { Interactive Learning Multimedia makes it easier for } \\
\text { me to understand the material. }\end{array}$ & 4.7 & Good \\
\hline 2 & $\begin{array}{l}\text { Interactive Learning Multimedia makes it easier for } \\
\text { me to understand English vocabulary. }\end{array}$ & 4.4 & Good \\
\hline 3 & The letters used to make it easy for me to read MPI. & 4.5 & Very Good \\
\hline 4 & The proportion of images on the media is appropriate. & 4.6 & Very Good \\
\hline 5 & Sound and music quality on the media is good. & 4.3 & Very Good \\
\hline 6 & Use of examples in accordance with daily life. & 4.8 & Very Good \\
\hline 7 & The material in MPI is interesting. & 4.5 & Very Good \\
\hline 8 & $\begin{array}{l}\text { The sentences used in MPI are clear and easy to } \\
\text { understand. }\end{array}$ & 4.5 & Good \\
\hline 9 & $\begin{array}{l}\text { The language used in MPI is simple and easy to } \\
\text { understand. }\end{array}$ & 4.3 & Very Good \\
\hline \multirow[t]{3}{*}{10} & The letters used are simple and easy to read. & 4.7 & Good \\
\hline & Total & 4.53 & \\
\hline & Average & 4.53 & Very Good \\
\hline
\end{tabular}


used, namely the experimental class, class 7B which uses interactive learning multimedia and $7 \mathrm{C}$ class, control class that uses 2013 Curriculum student books. Each experimental and control class has 32 students each. The pretest and posttest data results in the experimental class and the control class were analyzed by using a $t$-test (independent samples $t$-test) with the help of SPSS software version 16.0 for windows. After that, the prerequisite test analysis for the pretest and posttest data in the experimental class and the control class were explored. Table 8 presents the results of the pretest and posttest normality test.

After the analysis of prerequisite tests for pretest and posttest data, it is found the experimental and control classes have normal and homogeneous data. The next is the $t$-test analysis using SPSS software version 16.0 for windows. Data requirements are significant if the significance $(p)$ is less than 0.05 . Table 9 shows the pretest and posttest homogeneity test results.
Then, calculation is conducted on the effect of using MPI in the experimental class and the use of the 2013 Curriculum book media using a $t$-test. The results of the $t$-test analysis showed that there were significant differences between the experimental class using interactive learning multimedia in English learning compared with the control class using 2013 Curriculum student books at SMP N 2 Turi. This is indicated by the obtained $t_{\text {count }}$ of 6.009 with df of 62 and $t_{\text {table }}$ of 1.530 at a significant level of 0.000 then the $t_{\text {count }}$ is greater than $t_{\text {table }}$ (th: $6.009>\mathrm{tt}$ : 1.530 ) or the significance of 0.000 below the $p_{\text {value }}<0.05$. Table 10 presents the result of the $t$-test.

The experimental class that used interactive learning multimedia gained an average posttest score of 79.06. Meanwhile, the control class that used the 2013 Curriculum students' books in English obtained an average posttest score of 68.75 .

The analysis phase was carried out by the researchers to find out the students'

Table 8

The Result of Normality Test of Pretest and Posttest of Experimental and Control Class

\begin{tabular}{llccc}
\hline \multirow{2}{*}{ Class } & \multicolumn{3}{c}{ Shapiro-Wilk } \\
\cline { 3 - 5 } Pre-test & Control Class & .923 & 32 & .024 \\
& Experimental Class & .899 & 32 & .006 \\
Post-test & Control Class & .949 & 32 & .137 \\
& Experimental Class & .943 & 32 & .090 \\
\hline
\end{tabular}

Table 9

The Result of Homogeneity Test of Pretest and Posttest of Experimental and Control Class

\begin{tabular}{lcccc}
\hline & Levene Statistic & df1 & df2 & Sig. \\
\hline Pre-test & .076 & 1 & 62 & .784 \\
Post-test & .865 & 1 & 62 & .356 \\
\hline
\end{tabular}


Wahyu B. \& Sujarwo: Interactive Learning Multimedia...

Table 10

The Result of t-Test of Experimental and Control Class

\begin{tabular}{cccc}
\hline Resource & df & Significance $(\mathrm{p})$ & Description \\
\hline Posttest & 62 & 0.000 & Significance $(\mathrm{p}=0.000<0.05)$ \\
\hline
\end{tabular}

needs in learning and the problems faced by students in learning, then the researcher determined the solution to resolve the problem. Finally, it was decided that developing MPI was the right solution to help students learn easily and pleasantly. The analysis phase was completed after that it was continued with the design phase to develop MPI as an alternative learning media that supports the learning process. At the design stage of the activity were formulating learning objectives: determining learning material, strategies, and evaluations. So in this stage, it required effective steps in designing learning programs. The first step taken was to make a draft of the implementation of learning (RPP) in accordance with $K I$ and $K D$, then arranging the material in accordance with the RPP and design multimedia interactive learning.

At the multimedia design stage, this interactive learning was carried out with different stages according to the needs of students that had been previously designed. These activities included making flowcharts then making storyboards. The final stage in designing was determining the form of assessment used to determine the effectiveness of learning multimedia products, namely cognitive assessment in the form of multiple-choice questions.

After the design phase was complete then it was continued with the development stage. At this stage, the experts involved in evaluating the media that had been developed, both media experts, material experts, teachers, and student responses. On the results of the assessment of media, experts obtained a pretty good result that is 4.55 which is categorized very well for the media used in the learning process. Based on the explanation from Table 2, it can be seen in several aspects to get the points above 4. It states that MPI is suitable for use in the process of learning English in class 7 of SMP N 2 Turi. This is supported by Nugroho, Putra, Putra, and Syazali (2017) who obtained results based on the media aspect is a value of 4.7 from validator 1 and obtained a value of 4.6 from validator 2 so that the average results obtained from media experts reached 4.65. This means that the media on the criteria is at the very good cateagory.

The results of the expert material assessment produced the final score for the aspect of material worth with a score of 4 . With a good category, the aspect of material accuracy with a score of 4.6 with a very good category, languages with a score of 5 with a good category, as well as material expertise with a score of 5 with a very good category. It can be seen that the material expert gives a good score in terms of the material available in MPI to be applied in the learning process. This is in accordance with Januarisman and Ghufron (2016) by obtaining data processing results from the validation of two material experts which has "good" and "very good" criteria with an average rating 3.73 and 4.23. An interactive multimedia learning assessment by a grade 7 English teacher in SMP N 2 gains an MPI product evaluator with the results of "SB" categorized as "Very Good" referring to Table 4. The assessment given by an English teacher in $S M P N 2$ Turi obtains 
very good results both in developing MPI aspects of the material contained as well as the media as a whole. On the results of the assessment of English teachers on interactive learning multimedia for media display aspects, it obtained an average of 4 results including the value of " $\mathrm{B}$ " with the category "Good".

Then the English teacher in interactive learning multimedia for the aspects of images and animations obtained an average of 4 including "B" grades in the "Good" category. The assessment of interactive learning multimedia for the text aspect obtained an average of 4 including the "SB" score with the "Very Good" category. Furthermore, the assessment of interactive learning multimedia for audio and video aspects gave an average of 4 including the "SB" score in the "Very Good" category. The English teacher also gave 4.1 grades "B" with the category "Good for the aspects of Material Feasibility. In the aspect of material accuracy, the results obtained an average of 4.2 , including the value of "SB" with the category "Very Good". Then the assessment on the language aspect obtained an average score of 4.4 including the "SB" score in the "Very Good" category. Data on the results of junior high school teacher evaluations on interactive learning multimedia for material skill aspects obtained an average of 4.5 including the "SB" score with the "Very Good" category. It can be concluded that the English teacher gives grades in the excellent category and is suitable for use in the learning process as another alternative media. The feasibility of the media developed by the researchers is in line with the results of Rasyid, Aziz, and Saleh (2016) which obtained the average value of eligibility from the validator for the feasibility of the media of 3.5 and the average value of eligibility for the material of 3.6 which means that this multimedia- based learning media in terms of media and material included is in the "decent" category.

To find out the effectiveness of MPI development was done by knowing the students' responses and testing. This is in accordance with Herawati and Muhtadi (2018) who said that the tests in the form of pretest and posttest questions were used to determine the effectiveness of interactive e-module products in improving student learning outcomes. In Table 5, the students' response data in the small group trials yielded relatively low results with an average of 2.9 included in the sufficient category. This happens because the small trial groups are the first time that students use interactive learning multimedia, students have never used MPI before. Students have not adapted to MPI developed by researchers so students are still awkward in operating it. At the time of data collection at the trial stage, small groups are classified as low due to many influential factors such as unfamiliarity with the use of media. It was also supported by research by Setiyorini, Patonah, and Murniati (2016) which obtained the results of limited trials to respondents with a total of 36 feasibility learning media in the form of Moodle on temperature and heat material was $85.27 \%$ (very feasible category).

After the data is obtained at the small group trial stage and carried out revisions in accordance with the criticisms and suggestions obtained, then the second trial is carried out namely operational trials. In the operational test phase, the data obtained is quite good compared to the trials in the small groups listed in Table 6. Obtained data on responses to multimedia interactive learning in the media aspect, the contents are included in the "Very Good" category with a value of 4.38 . From the student response data on operational tests, there are criticisms and suggestions from students, 
namely the color is too dark, the letters are difficult to read because the size is not large enough, and the color contrast. So, interactive learning multimedia in English $7^{\text {th }}$ grade Junior High School learning is revised and refined based on criticism and suggestions from students. Large group trials are slightly different from small group trials and operational tests because they use the experimental method. Additionally, at this stage is the implementation stage, where the use of MPI in the learning process is carried out. The experimental method involves two large classes, namely the experimental class and the control class. The experimental class is a class that used interactive learning multimedia in English learning while the control class is a class that used the $7^{\text {th }}$ grade student's book 2013 Curriculum 2013.

Subjects of students taken are not students who have been tested in small and operational groups. Therefore, a large trial group was conducted on 32 students from class $7 \mathrm{~B}$ as an experimental class and 32 students from class $7 \mathrm{C}$ as a control class which was used as an experimental and control class assisted by an English teacher in accordance with student abilities and student learning outcomes. Student response data in the large trial groups are only given to the experimental class students who use interactive learning multimedia to find out information about the media that has been developed by the researchers. Filling the data of the students' response is given after the students use interactive learning multimedia. After the student response, the result of data is obtained in a large group trial and then it is converted. In accordance with the data in Table 7 regarding student responses in large group trials, an average grade of 4.53 was obtained with a very good category. This is in agreement with the research of
Khotimah and Santosa (2016) who obtained the analysis results obtained by assessing each aspect, namely the design aspect was stated very good with a percentage of $86 \%$, the material aspect was stated very goodl with a percentage of $87 \%$, and the benefit aspect was stated to be very good with a percentage of $89 \%$.

At the evaluation stage, tests were conducted in the form of a pretest before using MPI and posttest after using MPI. After obtaining each of the pretest and posttest scores, a normality test was then performed. The pretest and posttest normality tests were carried out in the experimental class and the control class using SPSS software version 16.0 for windows that can be seen in Table 8. Data can be said to be normally distributed if the significance is above 0.05 . Provision of tests in the form of a pretest to find out students 'prior understanding before being given treatment and posttest to find out students' understanding after being given treatment. Then the homogeneity test of the pretest and posttest results was carried out in the experimental class and the control class which was then analyzed using SPSS software version 16.0 for windows in Table 9. The pretest and posttest results can be said to be homogeneous in distribution if the significance is above 0.05

After the analysis of prerequisite tests for the pretest and posttest data, the experimental and control classes have normal and homogeneous data. Next is the $t$-test analysis using SPSS software version 16.0 for windows. Data requirements are significant if the significance $(p)$ is less than 0.05 . The $t$-test results obtained significant 0.000 or 0.000 significance below the $p_{\text {value }}<0.05$. The experimental class that uses interactive learning multimedia obtains an average score of 79.06 while the control class that uses students' books 
Curriculum 2013 in English gets an average score of 68.75 . Thus, interactive learning multimedia effectively increases vocabulary mastery in learning English in $7^{\text {th }}$ grade junior high school 2 Turi. The results are in accordance with the results of research from Heriyanto, Haryani, and Sedyawati (2014) on the use of MPI tests based on education games effectively applied to the learning of colloidal system chemistry in class XI SMA 1 Subah with the completeness of $94.44 \%$ (KKM 75), very good interest at $83.33 \%$ and very high activity at $86.11 \%$.

\section{CONCLUSION}

Interactive learning multimedia has been produced to improve the mastery of vocabulary in learning English of $7^{\text {th }}$ grade SMP 2 Turi with ADDIE models with five stages. First, analyze. Including the stage of identifying instructional needs, analysis of general instructional goals, and identification of students' initial characteristics. Second, design. Including the stages of designing special instructional, designing multimedia interactive learning frameworks, and developing quality and effectiveness assessment instruments. Third, development. Including the preparation of interactive learning multimedia, development, and revision. Fourth, implementation, carried out in small group trials, operational trials, and large group trials. Fifth, evaluation. Multimedia interactive learning English is appropriate to be used to improve the mastery of vocabulary in learning English in grade 7 Middle School 2 Turi. Based on the results of the due diligence test by media experts, material experts, and Junior High School English teachers, all aspects obtained a very good category.

Multimedia interactive English learning proved effective for increasing vocabulary mastery in learning English in grade 7
Middle School 2 Turi. The effectiveness of interactive learning multimedia is obtained from small group tests, operational tests, and large group trials based on student response data and tests. The experimental class that used interactive learning multimedia gets an average posttest score of 79.06 while the control class that used the 2013 Curriculum students' books in English gets an average posttest score of 68.75. In short, interactive learning multimedia effectively increases vocabulary mastery in learning English in grade 7 Middle School 2 Turi. In addition, researchers also hope that MPI can be used when learning English $7^{\text {th }}$ grade junior high school because it improves learning outcomes and students' vocabulary mastery and is used, as a variation of the learning media of $7^{\text {th }}$ grade junior high school students.

\section{REFRENCES}

Ahmad, I. (2010). Metodologi pembelajaran bahasa Inggris. Bandung: Humaniora.

Daryanto. (2013). Media pembelajaran, peranannya sangat penting dalam mencapai tujuan pembelajaran. Yogyakarta: Gava Media.

Harrington, M. (2018). Lexical facility size, recognition speed and consistency as dimensions of second language vocabulary knowledge. United Kingdom: Acid-Free Paper.

Herawati, N. S., \& Muhtadi, A. (2018). Pengembangan modul elektronik (e-modul) interaktif pada Mata Pelajaran Kimia kelas XI SMA. Jurnal Inovasi Teknologi Pendidikan, 5(2).

Heriyanto, A., Haryani, S., \& Sedyawati, S. M. R. (2014). Pengembangan multimedia pembelajaran interaktif berbasis education game sebagai media pembelajaran kimia. Chemistry in Education, 3(1),1-7. 
Januarisman, E., \& Ghufron, A. (2016). Pengembangan media pembelajaran berbasis web Mata Pelajaran Ilmu Pengetahuan Alam untuk siswa kelas VII. Jurnal Inovasi Teknologi Pendidikan, 3(2). Retrieved from https:// journal.uny.ac.id/index.php/jitp/ article/view/8019/8364.

Khan, I. A. (2011). Learning difficulties in English: Diagnosis and pedagogy in Saudi Arabia. International Research Journals, 2(7), 1248-1257.

Khotimah, A., \& Santosa, A. B. (2016). Pengembangan media pembelajaran multimedia interaktif pada Mata Pelajaran Perekayasaan Sistem Antena di SMK Negeri 5 Surabaya. Jurnal Pendidikan Teknik Elektro, 5(1), 237-243.

McCarthy, M., \& O’Dell, F. (2017). English vocabulary in use. United Kingdom: Cambridge University Press.

Munir. (2013). Multimedia konsep \& aplikasi dalam pendidikan. Bandung: Alfabeta.

Nopriyanti, \& Sudira, P. (2015). Pengembangan multimedia pembelajaran interaktif kompetensi dasar pemasangan sistem penerangan dan wiring kelistrikan di SMK. Jurnal Pendidikan Vokasi, 5(2), 222-235.

Nugroho, A. A., Putra, R. W. Y., Putra, F. G., \& Syazali, M. (2017). Pengembangan blog sebagai media pembelajaran matematika. Al-Jabar: Jurnal Pendidikan Matematika, $8(2)$. Retrieved from http://ejournal. radenintan.ac.id/index.php/al-jabar/ article/view/2028/1569.

Nunan, D. (1991). Language teaching methodology: A textbook for teacher.
Upper Saddle River, NY: Prentice Hall.

Papilaya, J. O., \& Huliselan, N. (2016). Identifikasi gaya belajar mahasiswa. Jurnal Psikologi, 15 (1), 56-63, Dec. 2016. https://doi.org/10.14710/ jpu.15.1.56-63.

Rasyid, M., Azis, A. A., Saleh, A. R. (2016). Pengembangan media pembelajaran berbasis multimedia dalam konsep sistem indera pada siswa kelas XI SMA. Jurnal Pendidikan Biologi, 7(2) 69-80.

Rusman, Kurniawan, D., \& Riyana, C. (2012). Pembelajaran berbasis teknologi informasi dan komunikasi: mengembangkan profesionalitas guru. Jakarta: Rajawali Pres.

Sanaky, H.A. H. (2013). Media pembelajaran interaktif-inovatif. Yogyakarta: Kaukaba Dipantara.

Saputra, W., \& Purnama, B. E. (2012). Pengembangan multimedia pembelajaran interaktif untuk mata kuliah organisasi komputer. Journal SpeedSentra Penelitian Engineering dan Edukasi, 4(2), 60-67.

Setiyorini, Patonah, S., \& Murniati, N. A. N. (2016). Pengembangan media pembelajaran moodle. Jurnal Penelitian Pembelajaran Fisika, 7(2), 156-160. http://dx.doi.org/10.26877/ jp2f.v7i2.1311.

Surjono, H. D. (2017). Multimedia pembelajaran interaktifkonsep dan pengembangan. Yogyakarta: UNY Press.

Widyoko, S. E. P. (2009). Evaluasi program pembelajaran.Yogyakarta: Pustaka Belajar. 